\title{
Mechanisms of bush encroachment and its inter-connection with rangeland degradation in semi-arid African ecosystems: a review
}

\author{
Anteneh BELAYNEH ${ }^{1}$, Zewdu K TESSEMA ${ }^{2 *}$ \\ ${ }^{1}$ Department of Biology, College of Natural and Computational Sciences, Haramaya University, Haramaya 282, Ethiopia; \\ ${ }^{2}$ Rangeland Ecology and Biodiversity Program, School of Animal and Range Sciences, College of Agriculture and \\ Environmental Sciences, Haramaya University, Dire Dawa 138, Ethiopia
}

\begin{abstract}
Many studies show that semi-arid rangelands throughout the world have been rapidly converted from a grassland state to a bush encroachment state during the past 50 years. Bush encroachment includes the spread of local woody species and/or incursion of woody species introduced from other ecosystems into semi-arid savannas and grassland ecosystems. Rangeland degradation due to bush encroachment causes several challenges, affecting the production of livestock and pastoral people livelihoods in most parts of Africa. Scientists have long been attempting to develop schematic and mathematical theories to explain the observed phenomenon of bush encroachment, and several theories were proposed and developed. The well-regarded theories include: (1) Walter's two-layer model, (2) Moir's one-layer model, (3) state-and-transition theory, (4) equilibrium theory, (5) disequilibrium theory, and (6) non-equilibrium theory. Within those theories, the most frequently-indicated driving factors that explain bush encroachment include over-grazing, availability of soil nutrient and moisture, elevated $\mathrm{CO}_{2}$ levels, frequency and intensity of fire, spread of seeds of woody species by livestock and wild animals. It should be stressed that couplings and interactions among diverse driving factors are more often at work in determining the condition of bush encroachment. To summarize, the effort in managing semi-arid ecosystems needs critical knowledge to understand the cause-effect relationships of underlying factors through integrated approach. Therefore, future research on encroachment of woody plants should be multi-discipline oriented and multi-partnership involved.
\end{abstract}

Keywords: climate change; exotic woody species; indigenous woody species; Moir's one-layer model; rangeland theories; Walter's two-layer model

Citation: Anteneh BELAYNEH, Zewdu K TESSEMA. 2017. Mechanisms of bush encroachment and its inter-connection with rangeland degradation in semi-arid African ecosystems: a review. Journal of Arid Land, 9(2): 299-312. doi: 10.1007/s40333-016-0023-x

\section{Introduction}

Most dry land ecosystems in Africa are characterized by distinctive vegetation types including grassland, savanna, woodland, scrubland, and desert (White, 1983; Friis and Vollesen, 2005). The vegetation structure and composition of these ecosystems have undergone dynamic changes over time, and ecosystem degradation resulted from bush encroachment has been documented to be one of the recent expressions of those dynamic changes (Bester and Reed, 1997; Briske et al., 2003; Reynolds et al., 2007; Eldridge et al., 2011). According to Ward (2005) encroachment of bush can be defined as "the aggression of destructive and unwanted woody plants, which causes a

*Corresponding author: Zewdu K TESSEMA (E-mail: tessemaz@yahoo.com)

Received 2016-04-14; revised 2016-09-18; accepted 2016-09-23

(C) Xinjiang Institute of Ecology and Geography, Chinese Academy of Sciences, Science Press and Springer-Verlag Berlin Heidelberg 2017 
disproportional increase in bushes and a decline in biological diversity, leading to a decline in grazing capacity of both wild and domestic herbivores in semi-arid rangeland ecosystems". The encroaching woody species include both indigenous and exotic woody species, and thus bush encroachment actually includes two kinds: (1) the proliferation of indigenous woody plant species and (2) the invasion of exotic/alien woody species in savannas and grassland ecosystems (Brown and Archer, 1989; Ward, 2005). It should be stressed that the second kind of bush encroachment, i.e., invasion of exotic/alien woody species, is a widespread phenomenon over most of the African savannas and grasslands (Hoffman and O’Connor, 1999; Oba et al., 2000; Smit, 2002; Ward, 2005; Gemedo et al., 2006; O’Connor et al., 2014).

Researchers have persistently attempted to explore those driving factors triggering encroachment of woody plants in the semi-arid environments (Archer et al., 1995; van Auken, 2000; Briske et al., 2003; Ward, 2005). Among many factors, continuous heavy grazing, frequent fires, declines in soil moisture and nutrient, and climate change associated global warming have been causally linked with encroachment of bushes or woody plants. However, it is yet difficult to attribute a single factor or a set of factors as the cause of the observed bush encroachment simply because most factors are spatially correlated and some of those factors are scale (both space and time) dependent (Walker, 1971; Archer et al., 1995; Scholes and Archer, 1997; Ward, 2005; van Auken, 2009; Archer, 2010; Tessema et al., 2012). Of course, encroachment of woody plants has been tied to the degradation of semi-arid rangelands, and thus often perceived negatively. However, recent studies suggest that encroaching woody species sometimes had positive effects on the structure and function of some ecosystems (Smit, 2002; Gemedo et al., 2006; Maestre et al., 2009; O’Connor et al., 2014). To explain the locally-observed bush encroachment, three models were proposed in earlier times: (1) Walter's two-layer model (Walter, 1939), (2) Moir's one-layer model (Moir, 1954), and (3) state-and-transition system (Briske et al., 2003; Sankaran et al., 2004; Vetter, 2005). As longer-term data were accumulated from larger geographic areas and studies were further deepened, more comprehensive theoretical schemes have emerged. The following three theoretical schemes are well regarded: (1) equilibrium rangeland system, (2) disequilibrium rangelands system, (3) non-equilibrium rangeland system. This paper attempts to provide a comprehensive review of published works primarily on the observed bush encroachment and the associated degradation of rangelands in the dryland ecosystems in Africa. The debated causes and the proposed mechanisms are critically reviewed and the practical implications for developing mitigation and adaptation strategies are also discussed.

\section{Concept of bush encroachment}

Encroachment of bush, i.e., the spread of indigenous woody species and/or incursion of woody species introduced from other ecosystems into semi-arid savannas and grassland ecosystems, has been widely reported phenomena (Prins and Van der Jeugd, 1992; Gibbens et al., 2005; Van Auken, 2009). For example, proliferation of woody plants was documented as a well understood threat in many semi-arid savannas during the twentieth century and has later came out as one of the major recognized threats of rangelands (Hoffman and O’Connor, 1999). Previous studies indicated that semi-arid savannas and grassland ecosystems globally have been changed by bush encroachment in the past 50 years (Ward, 2005). Again, encroachment of bush refers to the spread of indigenous or/and exotic woody plants in savannas and grassland ecosystems (Bews, 1917; Van Auken, 2009).

The phrase "bush encroachment" is similar with other commonly-used vocabularies such as thickening of woody plants (Van Auken, 2009), woody re-growth (Eldridge et al., 2003), invasion of woody weed (Ayres et al., 2001), xerification (Archer, 2010), and invasion of shrubs (Noble, 1997). Other authors defined encroachment of bush from the perspectives of grazing and browsing values of encroaching woody plant species and productivity. For example, encroachment or incursion of bush could be defined as the destruction or overthrow of pleasant grass species by bushes and/or shrubs, which are often indigestible to herbivores (Ward, 2005). The phenomenon of bush encroachment, which was described in different terminologies, was 
reportedly widespread in arid and semi-arid savannas and grasslands in most parts of the world such as in North and South Americas, Africa, south-east Asia, and Australia (Prins and Van der Jeugd, 1992; Eldridge et al., 2011). It was demonstrated to have caused herbaceous vegetation loss in many semi-arid grasslands and savannas (Oba et al., 2000; Abule et al., 2005; O’Connor et al., 2014).

Furthermore, invasion by bush has been tied to rangeland degradation and thus often perceived negatively (Gemedo et al., 2006). The well-known negative connotation was given by Ward (2005) and the connotation defined encroachment of bush as "the aggression of destructive and unwanted woody plants, which causes a disproportional increase in bushes and a decline in biological diversity, leading to a decline in grazing capacity of both wild and domestic herbivores in semi-arid rangeland ecosystems”. However, recent studies suggest that encroaching woody species sometimes had positive effects on the structure and function of ecosystems (Smit, 2002; Gemedo et al., 2006; Maestre et al., 2009; O’Connor et al., 2014) and these woody species may also be indispensable resources such as fodder for both domestic and wild herbivores, sources of firewood, medicine, mulch, and more (Smit, 2002; Maestre et al., 2009; Eldridge et al., 2011). In addition, some published works suggested that shrubs could enhance resource stocks such as belowground carbon and nitrogen or aboveground net primary productivity (Maestre et al., 2009). The balance between the negative and positive effects of bush encroachment may have been juggled by the "degree" of bush encroachment. White (1980) reported that bush encroachment becomes a problem (i.e., negative) when trees, shrubs and bush covers exceed 30\%. More recent works found that an increase of $10 \%$ woody cover would lead to a decline of about $7 \%$ of the grazing potential and fodder resources in semi-arid rangelands (Oba et al., 2000). Price and Morgan (2008) found a significant reduction in the number of species and also in the emerging seeds of soils in areas with more than $15 \%$ coverage by an encroaching shrub in comparison with open areas.

\section{Concept of land degradation}

Studies indicated that degradation of land become a single major constraint in most rangeland ecosystems in dry lands of Africa (Ward, 2005; Gemedo et al., 2006; O’Connor et al., 2014). The key drivers of ecological changes in arid and semi-arid rangeland environments are those leading to degraded condition for primary productivity (Reich et al., 2000). The processes leading to the degraded conditions for primary productivity are called "land degradation". The worst-case scenario for land degradation in dry land ecosystems often termed as "desertification", which can be regarded as an appearance of a continual decrease in the capability of a dry land environment to offer various goods and services (Reich et al., 2000). UNCCD et al. (2009) defined "land" as a terrestrial biological productive system based on its primary productivity service, and land degradation is simply loss of provision of its primary productivity service of the land. Therefore, degradation of land can be described as "the decline or complete damage of the biological productivity and/or socioeconomic benefit of land in general”.

Some authors defined rangeland degradation as general declines in biotic and abiotic qualities including losses of topsoil, changes in flora/fauna composition, and continuous reduction of primary productivity (Barrow, 1991). Others defined rangeland degradation as measurable declines in aboveground and belowground biomass production, in carbon storage and soil quality, and also in water infiltration and holding capacities (Dregne, 2002; Richardson et al., 2005). A third group of authors examined rangeland degradation primarily from socioeconomic perspectives. They viewed rangeland degradation as processes resulting in the capacity reduction of the ecosystems to support primary productivity and livestock production (Illius and O’Connor, 1999).

\section{Discourse between bush encroachment and rangeland degradation}

Bush encroachment is explained to be a common problem of all dry lands globally (Bews, 1917; 
Archer, 1990; Hoffman and O’Connor, 1999; Oba et al., 2000; Smit, 2002; Gibbens et al., 2005; Gemedo et al., 2006; O’Connor, 2014), and the problem is the most serious in Africa. As aforementioned, bush encroachment has been tied to rangeland degradation and thus often perceived negatively (Gemedo et al., 2006). The causal linkages between encroachment of bush and degradation of rangeland have been the foci of scientific researches around the globe, especially in Africa, simply because bush encroachment poses serious difficulties to the socioeconomic development of dry lands (Vetter, 2005). Encroachment by bush is recognized as a major factor that aggravates degradation of rangeland in dry land areas of the world (Belay et al., 2013). For instance, more than $70 \%$ of rangelands have already experienced severe degradation (Dregne and Choun, 1992). Moreover, the swift incursion of woody plants into freely grazed areas shares a main responsibility to the reported rangeland degradation (Smit, 2002; Ward, 2005; Archer, 2010). Depending on the degree of bush encroachment and the characteristics of encroaching plants, encroachment of bush could adversely change the soil biological, physical, and chemical characteristics of the local biodiversity of rangeland ecosystems (Biederman and Boutton, 2009).

However, encroaching woody species sometimes had positive effects on the structure and function of various ecosystems (Smit, 2002; Gemedo et al., 2006; Maestre et al., 2009; O’Connor et al., 2014) and these woody species may also be indispensable resources (Smit, 2002; Maestre et al., 2009; Eldridge et al., 2011). For example, bush encroachment-resulted woody plants were reported to have significantly contributed to livestock fodder, particularly in drought periods (Moleele and Perkins, 1998; Gemedo et al., 2006) and deliver a variety of products and amenities for the pastoral people in many parts of Africa (Abule et al., 2007). For example, leguminous woody plants encroaching the rangelands can improve soil quality through nitrogen fixation (Kgosikoma et al., 2012). Although bush encroachment has been negatively perceived from pastoralism point of view (Illius and O’Connor, 1999; Gemedo et al., 2006; Van Auken, 2009), the positive ecological effects and the positive economic effects are also abundantly reported (Di Tomaso, 2000; Moleele et al., 2002; Parizek et al., 2002; Smith and Johnson, 2004; Maestre et al., 2009; Eldridge et al., 2011; Ratajczak et al., 2012). The nature of the effect depends on whether the encroaching woody species are trees or shrubs and on whether the encroaching woody species are indigenous or invasive. For instance, Angassa and Baars (2000) indicated that the total score of rangeland condition (a proxy for rangeland quality) was lower under bush encroached rangeland than non-encroached rangelands in Borana of southern parts of Ethiopia. It is now apparent that a straightforward description of bush encroachment could not be supported with critical explanation of available information. If a wider concept of land degradation is given to bush encroachment, its effects (negative or positive) on the structure and function of various ecosystems can be more fairly assessed.

\section{Indigenous and exotic woody species encroaching the semi-arid rangelands}

Both indigenous and exotic woody species are known encroachers of the semi-arid rangelands. Encroachment by woody species of the genus Acacia, Dichrostachys, Prosopis, Balanites, and Grewia in arid and semi-arid rangelands was widely reported from North America, South America, Asia, and Australia (Prins and Van der Jeugd, 1992; Ayres et al., 2001; Smit, 2002; Gibbens et al., 2005; Ward, 2005; Solomon et al., 2007), and encroachment by woody plant species (indigenous and exotic) was reported to have occurred in many parts of Africa (Hoffman and O'Connor, 1999; Smit, 2002; Ward, 2005; Gemedo et al., 2006; Russell and Ward, 2014; Ward et al., 2014). A host of other woody species was also reported to have encroached into rangelands and savannas, like Maytenus, Euclea, and Acalypha species. Table 1 includes the most common native woody species of trees and shrubs collected from published literatures to indicate how the grasslands and savannah rangelands are severely encroached by plants of various woody species in the semi-arid ecosystems. 
Table 1 Most common encroached indigenous woody species in the semi-arid rangelands

\begin{tabular}{|c|c|c|c|}
\hline Family & Species & Regions & Sources \\
\hline \multirow[t]{5}{*}{ Fabaceae } & $\begin{array}{l}\text { Acacia senegal, A. nubica, } \\
\text { A. melifera, A. nilotica, A. tortilis, } \\
\text { A. seyal, A. karroo, A. hebeclada, A. } \\
\text { etbaica, A. erubescens, A. sieberiana, } \\
\text { A. erioloba, A. brevispica, } \\
\text { A. bussei, A. reficiens }\end{array}$ & $\begin{array}{l}\text { Africa, Australia, } \\
\text { North America }\end{array}$ & $\begin{array}{l}\text { O’Connor (1991); Ayres et al. (2001); } \\
\text { Smit (2003); Ward (2005); } \\
\text { Gemedo-Dalle et al. (2006); } \\
\text { Abule et al. (2007); Tefera et al. } \\
\text { (2007); Russell and Ward (2014); } \\
\text { Ward et al. (2014) }\end{array}$ \\
\hline & Dichrostachys cinerea & Africa & Hottman and O’Connor (1999) \\
\hline & Ormocarpum mimosoides & Africa & Tefera et al. (2007) \\
\hline & Prosopis africana, P. tamarungo & $\begin{array}{c}\text { Africa } \\
\text { Australia }\end{array}$ & $\begin{array}{l}\text { Bester and Reed (1997); } \\
\text { Ayres et al. (2001) }\end{array}$ \\
\hline & $\begin{array}{l}\text { Prosopis cineraria, } P \text {. farcta, } \\
\text { P. koelziana }\end{array}$ & Asia & Gibbens et al. (2005) \\
\hline Tiliaceae & $\begin{array}{l}\text { Grewia rewiaflava, G. bicolor, } \\
\text { G. tenax, G. villosa, } \\
\text { G. tembensis }\end{array}$ & Africa & $\begin{array}{l}\text { Gemedo-Dalle et al. (2006); } \\
\text { Eldridge et al. (2011) }\end{array}$ \\
\hline Balanitaceae & Balanites aegyptiaca & Africa & Abule et al. (2007) \\
\hline \multirow[t]{2}{*}{ Capparaceae } & Cadaba rotundifolia & Africa & Richter et al. (2001) \\
\hline & Capparis tomentosa & $\begin{array}{l}\text { Africa } \\
\text { Australia }\end{array}$ & Prins and Van der Jeugd (1992) \\
\hline \multirow[t]{2}{*}{ Anacardiaceae } & Rhus natalensis & Africa & Gemedo-Dalle et al. (2006) \\
\hline & Lannea floccosa & Africa & Tefera et al. (2007) \\
\hline \multirow[t]{2}{*}{ Combretaceae } & $\begin{array}{l}\text { Terminalia brownie, } \text { T. prunioides, } \\
\text { T. sericea }\end{array}$ & Africa & $\begin{array}{l}\text { Abule et al. (2007); } \\
\text { O’Connor et al. (2014) }\end{array}$ \\
\hline & Combretum molle & Africa & Tefera et al. (2007) \\
\hline Celastraceae & Maytenus spp. & Africa & Tefera et al. (2007) \\
\hline Euphorbiaceae & Acalypha fruticosa & Africa & Smit (2003) \\
\hline Ebenaceae & $\begin{array}{l}\text { Euclea crispa, E. divinorum } \\
\text { E. shimperi }\end{array}$ & $\begin{array}{c}\text { Africa } \\
\text { Asia }\end{array}$ & Russell and Ward (2014) \\
\hline Bignoniaceae & Rhigozum trichotomum & Africa & $\begin{array}{l}\text { O’Connor et al. (2014); } \\
\text { Ward et al. (2014) }\end{array}$ \\
\hline \multirow[t]{2}{*}{ Asteraceae } & Tarchonanthus camphoratus & Africa & $\begin{array}{l}\text { O’Connor et al. (2014); } \\
\text { Ward et al. (2014) }\end{array}$ \\
\hline & Pentzia incana & Africa & Ward et al. (2014) \\
\hline Burseraceae & Commiphora africana & Africa & Tefera et al. (2007) \\
\hline Rhamnaceae & Ziziphus mucronata, Ziziphus sp. & Africa & Smit (2003); O’Connor et al. (2014) \\
\hline Aloaceae & Aloe schimperiana & Africa & Tefera et al. (2007) \\
\hline Rubiaceae & Gardenia volkensii & Africa & Tefera et al. (2007) \\
\hline
\end{tabular}

The main genus of exotic plants of woody species encroaching rangelands in North and South Americas, Africa and Australia are Acacia, Prosopis, Opuntia, Lanthana and Larrea (Abule et al., 2005; Gemedo et al., 2006; Van Auken, 2009; Eldridge et al., 2011; O’Connor et al., 2014). Some of the common undesirable noxious (exotic or alien) woody plant species of these genus and others are indicated in Table 2. It should be mentioned that although indigenous bush encroachment or spreading generally poses great threats to the existing ecological structure and function in semi-arid rangelands, exotic bush encroachment or invasion is associated with greater threats to the existing ecological structure and function.

\section{Bush encroachment mechanisms}

To explain the locally-observed bush encroachment, researchers proposed two models in earlier times: (1) the two-layer model of Walter and the one-layer model of Moir. As studies were later deepened, more comprehensive theories have emerged and four theories were put forward: (1) 
Table 2 Most common encroached exotic woody species in the semi-arid rangelands

\begin{tabular}{|c|c|c|c|}
\hline Family & Species & Regions & Sources \\
\hline Fabaceae & $\begin{array}{l}\text { Acacia mearnsii, A. nubica, } \\
\text { A. drepanolobium, A. horrida, A. } \\
\text { saligna, A. xanthoploea } \\
\text { Prosopis glandulosa, } \\
\text { P. velutina, P. torreyana, } \\
\text { P. juliflora } \\
\text { Senna didemobotrya }\end{array}$ & $\begin{array}{l}\text { Africa, South America, } \\
\text { Mexico } \\
\text { North America, Africa, } \\
\text { South America, Mexico } \\
\text { Africa }\end{array}$ & $\begin{array}{l}\text { Gemedo-Dalle et al. (2006); } \\
\text { O’Connor et al. (2014); } \\
\text { Russell and Ward (2014) } \\
\text { Archer (1990); Richter et al. } \\
\text { (2001); Van Auken (2009) } \\
\text { Gemedo-Dalle et al. (2006) }\end{array}$ \\
\hline Verbenaceae & $\begin{array}{l}\text { Lanthana camara, } \\
\text { L. trifolia }\end{array}$ & Africa & Abule et al. (2007) \\
\hline Cactaceae & Opuntia stricta & $\begin{array}{l}\text { North America, Africa, } \\
\text { South America }\end{array}$ & $\begin{array}{l}\text { Grover and Musick (1990); } \\
\text { Schmutz et al. (1991) }\end{array}$ \\
\hline Zygophyllacceae & Larrea tridentata & North America & Van Auken (2009) \\
\hline Asteraceae & Gutierrezia sp. & North America & Van Auken (2009) \\
\hline \multirow[t]{2}{*}{ Euphorbiaceae } & Euphorbia tirucalli & Africa & Tefera et al. (2007) \\
\hline & Calitropis procera & Africa & $\begin{array}{l}\text { Nott and Savage (1985); } \\
\text { Zewdu and Oustelet (2007) }\end{array}$ \\
\hline Apocynaceae & Cryptostegia grandiflora & Africa, Australia & $\begin{array}{l}\text { Ayres et al. (2001); Eldridge et } \\
\text { al. (2003); Abule et al. (2007) }\end{array}$ \\
\hline Asparagaceae & Dracaena afromontana & Africa & Abule et al. (2007) \\
\hline Solanaceae & Solanum incanum, S. somalense & Africa & $\begin{array}{l}\text { Richter et al. (2001); } \\
\text { Zewdu and Oustelet (2007) }\end{array}$ \\
\hline
\end{tabular}

state-and-transition, (2) equilibrium, (3) disequilibrium, and (4) non-equilibrium rangeland theories.

\subsection{Walter's two-layer model}

This model described that grass species out-compete trees in the grasslands of the semi-arid savannas since they grow faster and intercept moisture from the top layer of the soil, thus inhibiting trees from potential contact to moisture in the deeper layers of the soil, where roots of tree are mostly found (Walter, 1939). The cover of grasses declined when there is heavy grazing pressure in dryland rangelands. Then soil moisture becomes available to the trees, and such condition would benefit trees and bushes and allow them to dominate in dryland environments. However, there is no indication that the soil hydrological and chemical characteristics change with grazing pressures, thus undermining the two-layer model of Walter (Jeltsch et al., 1996). This is more relevant in rangeland ecosystems encroached by Acacia mellifera in which the lateral roots of $A$. mellifera are well-known to extend mainly within the root zone of various grass species (Adams, 1966).

\subsection{Moir's one-layer model}

This model states that a constant nitrogen loss through grass fires could limit grass growth and capacity to the power of Acacia bushes, which are nitrogen-fixing (Moir, 1954 as cited in Adams, 1966). However, Brunt (1964 as cited in Adams, 1966) found no proof to elaborate the reported connection between nitrogen in soil and the density of Acacia, and this concept was thus rapidly dishonoured. However, Ward (2005) showed that adding nitrogen to the soil does suppress the seedling establishment of $A$. mellifera, implying that this model may need revisitation. All in all, due to the complexity of savannas and grasslands ecosystems the use of a simple model, which concentrates on sole factor, may not be helpful in understanding the causes of bush encroachment.

\subsection{State-and-transition ecosystem}

Rangelands in dryland environments are described by state-and-transition models as ecosystems with more than one state and as transition from one state to another, often occurring under influence of biotic and abiotic factors (Noy-Meir, 1975; Westoby et al., 1989; Rietkerk et al., 1996; Bestelmeyer et al., 2003; Van Langevelde et al., 2003; Briske et al., 2005). This model also makes distinction between stable states and transitions of semi-arid savannas (Westoby et al., 1989). “Transitions” between stable states can be initiated by natural "events” (e.g., weather, soil 
erosion, and fire) or by management "actions" (e.g., change in grazing pressure, and fire) (Briske et al., 2003). However, there is no common and definite consensus on how those driving factors operate at various scales in diverse rangeland ecosystems (Vetter, 2005; Ward, 2005).

\subsection{Equilibrium rangeland ecosystem}

The equilibrium rangeland ecosystem suggests that rangelands respond to the environment under the influence of grazing in a sequential and predictable manner. This kind of ecosystem is characterized by a relatively stable rainfall and also by a more or less constant tree-grass ratio. However, continuous and sustained heavy grazing in dryland rangeland ecosystem can initiate encroachment of woody plants by changing the competitive balance among grass swards and woody plants in semi-arid environments (Briske et al., 2003; Sankaran et al., 2004).

\subsection{Disequilibrium rangeland ecosystem}

This is a kind of rangeland ecosystem characterized by the continuing perseverance of the tree-grass balance. The balance is maintained by fire burning and herbivore grazing. Human dominance of those instabilities may result in dryland rangeland deterioration and thus lead to woody plant encroachment (Behnke et al., 1993; Sankaran et al., 2004).

\subsection{Non-equilibrium rangeland ecosystem}

Non-equilibrium rangeland systems are supposed to be determined primarily by abiotic factors, mostly variable rainfall, resulting in highly unpredictable and variable rangeland productivity. This kind of ecosystem is characterized by an unstable rainfall, leading to fluctuations in tree-grass balance. That is, woody plants may overgrow grasses during rainy seasons, whereas grass species may overgrow woody plants during drier periods (Briske et al., 2003; Kerstin et al., 2005; Sankaran et al., 2005; Vetter, 2005). Under the non-equilibrium rangeland system, livestock population has negligible feedback on the vegetation as their population seldom reaches stability with the fluctuating rangeland resources (Vetter, 2005).

\section{Driving factors involving in bush encroachment}

In the aforementioned mechanisms on bush encroachment, various driving factors were discussed (Table 3). Among them several are reported to be quite active in triggering the current encroachment of indigenous and exotic woody plant into grasslands and savannas in arid and semi-arid areas around the globe (Prins and Van der Jeugd, 1992; Smit, 2002; Van Auken, 2000). It should be particularly noted that combined effects of several driving factors and interacting effects of some driving factors were attributed to the bush encroachment, but the quantitative definition of the combined effects and the underlying processes of the interacting effects are still issues under heated debates (Van Auken, 2009; O’Connor et al., 2014). Following is our brief review on the reported driving factors of bush encroachment.

\subsection{Precipitation variability}

Due to the highly irregular precipitation and the vanishing of palatable grasses during the dry seasons, trees and shrubs become an important part in the semi-arid environments (Gemedo et al., 2006). Under such environments, encroachment of bush is always related with annual and inter-annual moisture variabilities (Briske et al., 2003; Angassa and Oba, 2007). At local scales, a continual wet period (i.e., a high amount of mean annual precipitation in multiple and consecutive years) can effectively promote a considerable increase in the cover of woody vegetation (Kerstin et al., 2005; Sankaran et al., 2005). For example, the encroaching of A. mellifera needs a minimum of three years of successive higher-than-average precipitation to recruit successfully. The importance of precipitation in controlling woody plant growth was well demonstrated by Sankaran et al. (2005). They reported that the percentage of woody plant is linearly correlated with the mean annual rainfall in African savannas. Simply, increased soil moisture allows the seedlings of woody plant species to stay alive and to establish into bush coppices. However, drought limits the growth of woody plant and even leads to shrivel up of plants of woody species 
Table 3 Drivers of bush encroachment reported in published studies

\begin{tabular}{ll}
\hline Driver of bush encroachment & Reference \\
\hline Heavy grazing pressure & Bothma (2002); Sankaran et al. (2004) \\
Reduced mobility of animals and break down of traditional land & Oba et al. (2000); Abule et al. (2007) \\
Change in fire frequency and intensity & Oba et al. (2000); Bothma (2002); Van Auken (2009) \\
Absences and misuse of fire & Belay et al. (2013); O’Connor et al. (2014) \\
Raising atmospheric $\mathrm{CO}_{2}$ concentration & Buitenwerf et al. (2012) \\
Climate change & Van Auken (2000, 2009) \\
$\begin{array}{l}\text { Expansion of cultivation } \\
\text { Nitrogen deposition }\end{array}$ & Abule et al. (2007) \\
Nutrient availability and rainfall patterns & Köchy and Wilson (2001) \\
Soil moisture stress & Sankaran et al. (2004); Ward (2005) \\
Soil nutrient levels & Van Auken (2009) \\
Kind of herbivory & Ward (2005) \\
Weakening of the grass stratum by drought & Van Auken (2009); O’Connor et al. (2014) \\
Spread of seed by livestock & Clarke et al. (2000); Gemedo-Dalle et al. (2006) \\
\hline
\end{tabular}

(Roques et al., 2001). Therefore, encroachment of bush and/or shrub is a cyclic natural phenomenon modulated by precipitation variability.

\subsection{Grazing frequency and intensity}

In the semi-arid savannas, plant composition is dependent upon the types of herbivore species and their grazing frequency and intensity (Allred et al., 2012). High levels of herbivore grazing can cause a rapid lessening of aboveground grasses and herbaceous biomass. Limited alterations in biomass of grasses over an extended period are not easy to observe since the aboveground parts are substituted yearly and rapidly by mobilization of stored resources in belowground (Bahre, 1991; Adler et al., 2001). If surface soil resources are used up or eroded away, grasses and herbaceous biomass and productivity aboveground would decrease. However, sustained and heavy grazing by herbivore would reduce the biomass of herbaceous vegetation both aboveground and belowground. Similarly, constant heavy grazing prompts a decline both in the aboveground vegetation and soil seed banks in semi-arid rangelands of Ethiopia (Tessema et al., 2012).

Generally, the processes that can decrease the biomass of grass or its ability to utilize moisture on the top soil and/or groundwater should be the processes that can increase the establishment of woody plants (Brown and Archer, 1989). According to Moleele and Perkins (1998) degradation of rangelands, including encroachment of bush, is linked with high density of cattle around the water points such as boreholes (wells) and kraals in semi-arid African savannas. Moreover, Abule et al. (2007) noted that besides heavy grazing, expansion of cultivation and inhibition of animals' mobility are also important factors contributing to bush encroachment. It should be stressed that overgrazing is the dominant factor leading to bush encroachment in Africa since it removes grass species and favors growth of woody plants (Skarpe, 1990). Grazing was also described to contribute to the encroachment of bush through seed dispersal of encroaching woody plant species (Scholes and Archer, 1997). However, there are also studies that dispute against the over-grazing proposition. For example, Oba et al. (2000) found that heavy grazing was not related significantly to the cover of bush in semi-arid rangelands of Borana and that the adopted mitigation protocols such as dropping livestock concentrations in periods of low rainfall have been unsuccessful in decreasing bush invasion (Ward, 2005).

\subsection{Change in fire frequency and intensity}

Fire is widely recognized as a vital factor in maintaining habitat quality in grassland ecosystems. Without fire, bush encroachment could have created a high risk of damage of grassland fodders for both domestic and wild herbivores and threatened the service functions of semi-arid 
rangelands (Gottfried et al., 2009; Bowman et al., 2011). According to the type of woody species and intensity of fire, fire may also help sprouting of seed through breaking dormancy or inhibit germination by destroying of seeds of trees with softer seed coats (Bradstock and Auld, 1995). As stated by Kgosikoma et al. (2012), both pastoralists and ecologists agree that lack of consistent burning may allow a large-scale proliferation of woody vegetation. Systematic and consistent fire suppresses the growth of woody plants by abolishing the bushes and young trees, and so prevents their growth into old plants of woody species (Mphinyane et al., 2011). Besides human fire-suppressing actions, human-promoted over-grazing is also an effective fire-suppressing factor because over-grazing limits surface fuel load and thus discourages frequent burning.

\subsection{Availability of soil nutrients}

The nature of leguminous woody plants $\mathrm{N}_{2}$-fixation ability contributes highly to their success in poor dryland locations (Van Auken et al., 1985). Furthermore, seedlings of trees are almost completely dependent up on cotyledons during germination for their requirements of nutrient up to the early stages of seedling establishment (Ernst, 1988). Accordingly, nitrogen should be a fundamental restraining factor to the fast growing of small-seeded grasses than to the slow growing large-seeded trees and shrubs. It was speculated that increased nitrogen in the soil would encourage herbaceous plants growth and thus discourage establishment of tree seedlings of $\mathrm{N}_{2}$-fixing species (Moshe et al., 2000). If this speculation can stand for tests, nutrient-poor situations should be more liable to encroachment by plants of woody species (at least by $\mathrm{N}_{2}$-fixing woody species) than nutrient-rich environments. Sankaran et al. (2005) reported that the cover of woody plants is undesirably associated with the clay content of the soil, and bush encroachment is thus likely to occur in sandy soil with low clay content in the Kalahari sands of Botswana (Kgosikoma et al., 2012). Assuming that clay content of the soil is positively related with nutrient level in the soil, the data of Sankaran et al. (2005) offer additional backing to the speculation that a rise of nitrogen content in the soil would encourage growth of herbaceous plants, and thus discourage establishment of tree seedlings. A comprehensive investigation of the cover of woody plants in African savannas also indicated that cover of woody plants was negatively related with soil nitrogen level, and then, increased deposition of nitrogen may decrease encroachment of bush (Sankaran et al., 2008). In contrast, Roques et al. (2001) indicated that type of soil had no significant effect on dynamics of shrubs in semi-arid savannas of Africa.

\subsection{Elevated levels of atmospheric $\mathrm{CO}_{2}$}

An increase in global $\mathrm{CO}_{2}$ concentration may have promoted $\mathrm{C}_{3}$ species of woody plants at the cost of $\mathrm{C}_{4}$ grasses (Eldridge et al., 2011). Considerable data are accessible to show that many $\mathrm{C}_{4}$ taxa substituted some $\mathrm{C}_{3}$ taxa during former glacial periods (lower atmospheric $\mathrm{CO}_{2}$ ) with a reversal of the trend during successive interglacial periods (higher atmospheric $\mathrm{CO}_{2}$ ) (Ehleringer, 2005). The recent tendency of increasing atmospheric $\mathrm{CO}_{2}$ has been going on through the past 11,500 years of the Holocene (i.e., recent interglacial). Accordingly, amplified atmospheric $\mathrm{CO}_{2}$ levels have been expected as the reason of recent encroachment of $\mathrm{C}_{3}$ woody plants into grasslands and savannas throughout the arid and semi-arid rangelands (Idso, 1992; Polley et al., 1992). Nevertheless, the replacement of species in earlier periods was possibly $C_{4}$ and $C_{3}$ grasses, not $\mathrm{C}_{3}$ woody plants, thus undermining the acceptability of the atmospheric $\mathrm{CO}_{2}$-related hypothesis of Ehleringer (2005). However, the atmospheric $\mathrm{CO}_{2}$-related hypothesis seems to be revitalized by the observed relationship between increased woody plant density and rising atmospheric $\mathrm{CO}_{2}$ levels (Morgan et al., 2007). The revitalized theory appears to be able to explain the widespread encroachment of woody plants into arid and semi-arid grasslands and savannas in the past 160 years (Van Auken, 2009).

The atmospheric $\mathrm{CO}_{2}$-related hypothesis is based on opinions that most woody plants have the $\mathrm{C}_{3}$ photosynthetic pathway and that numerous grasses that have been replaced in south-western grasslands have the $\mathrm{C}_{4}$ photosynthetic pathway, the $\mathrm{C}_{3}$ photosynthetic pathway being beneficial at higher levels of $\mathrm{CO}_{2}$ (Ehleringer, 2005). It should be noted that some of these replaced grasses have the $\mathrm{C}_{3}$ photosynthetic pathway. This hypothesis is facing a dilemma (Archer et al., 1995). That is, many $\mathrm{C}_{3}$ and $\mathrm{C}_{4}$ species have similar quantum yields, rates of photosynthesis, and 
water-use efficiencies. Several $\mathrm{C}_{4}$ grasses are quicker to respond to amplified levels of $\mathrm{CO}_{2}$ than originally understood. The replacement of $\mathrm{C}_{3}$ grasses by encroachment of $\mathrm{C}_{3}$ woody shrubs in desert ecosystems is not explainable by atmospheric $\mathrm{CO}_{2}$-related hypothesis. For example, in south-western North American semi-arid grasslands, $\mathrm{C}_{3}$ woody plants are substituting both the $\mathrm{C}_{4}$ grasses and $\mathrm{C}_{3}$ grasses. Besides, $\mathrm{C}_{3}$ grasses are not substituting $\mathrm{C}_{4}$ grasses under the recent atmospheric $\mathrm{CO}_{2}$-rising condition. Unexpectedly, in areas with similar biotic and abiotic rangeland conditions, replacement of populations of $\mathrm{C}_{4}$ grasses with $\mathrm{C}_{3}$ grasses has not happened. In brief, the atmospheric $\mathrm{CO}_{2}$-related hypothesis or the $\mathrm{CO}_{2}$ enrichment hypothesis as a mechanism of bush encroachment does not seem to be yet supported by sufficient data (Van Auken, 2009).

\section{Suggested strategies for controlling bush encroachment}

Encroachment of bushes must unambiguously be viewed as societal problem at national, regional, and global levels and just not as isolated problem to pastoralist community alone. This indicates that government, pastoralists, concerned stockholders, and the private sector need to act together to search for solution. Different coping strategies were suggested by different studies. Moreover, pastoralists and ecologists agreed that disappearance of consistent fire has facilitated the spreading of woody species (Kgosikoma et al., 2012). Consequently, depending on the availability of fuel biomass, burning should be an essential component of dryland savanna ecosystems. When the significant of fire is understood, establishment of institutions is essential to develop scientifically sounding burning regimes of savanna ecosystems (Fatunbi and Dube, 2008). Scientifically, proper burning as a control strategy of bush encroachment requires the acquaintance of upcoming climatic situations and the knowledge of minimizing its adverse impacts (e.g., air pollution and carbon emission).

The main emphasis must be placed on the development of strategies that can prevent the grasslands from bush encroachment. For instance, a community-based investigation in Borana of southern Ethiopia the perception and attitude of pastoralists were reported to have provided an insight into the management and control of bush encroachment (Gemedo et al., 2006). Since pastoralists are the most important stakeholders of rangelands in Africa, their perceptions may hold the key to the success in controlling bush encroachment. Moreover, pastoralists believe that a ban on fire is one of the factors causing bush encroachment and re-introduction of fire and consolidation of customary rangeland management approaches are strongly favoured. In brief, the success in controlling bush encroachment depends on our better understanding of underlying causes and also on our willingness to take an integrated approach. Therefore, future investigation on bush encroachment must be inter- and intra-disciplinary oriented through involvement of various partnerships.

\section{Conclusions}

Bush encroachment (including proliferation of indigenous woody plant species and invasion of exotic/alien woody species) is one of the most widespread phenomena in semi-arid rangelands of Africa. Unfortunately, its exact causes are not fully understood yet and the understanding requires an integrated approach to expanding the relevant scientific knowledge and to absorbing the indigenous ecological knowledge. Accordingly, a comprehensive use of the indigenous and customary ecological understanding and an effective expansion of the relevant scientific knowledge are so crucial to protecting the rangelands. Even if a single driving factor is often reported to be responsible for the observed bush encroachment, most reports concluded that couplings and interactions among different driving factors are more often at work in determining the transitions of arid and semi-arid grasslands and savannas to bush lands and woodlands. A number of studies reported both the synergies and trade-offs between bush encroachments and rangeland degradation in the semi-arid ecosystems. Rangeland degradation has a much wider connotation than bush encroachment. However, if a wider concept of degradation of rangeland is applied to encroachment of bush, it can envisioned that there are a range of positive, negative, and neutral effects of bush encroachment. 


\section{Acknowledgements}

The authors would like to acknowledge the information used in this review paper.

\section{References}

Abule E, Smit G N, Snyman H A. 2005. The influence of woody plants and livestock grazing on grass species composition, yield and soil nutrients in the Middle Awash Valley of Ethiopia. Journal of Arid Environments, 60(2): 343-358.

Abule E, Snyman H A, Smit G N. 2007. Rangeland evaluation in the middle awash valley of Ethiopia: II. Woody vegetation. Journal of Arid Environments, 70(2): 272-292.

Adams M E. 1966. A study of the ecology of Acacia mellifera, A. seyal and Balanites aegyptiaca in relation to land-clearing. Journal of Applied Ecology, 4(1): 221-237.

Adler P B, Raff D A, Lauenroth W. 2001. The effect of grazing on the spatial heterogeneity of vegetation. Oecologia, 128(4): 465-479.

Allred B W, Fuhlendorf S D, Smeins F E, et al. 2012. Herbivore species and grazing intensity regulate community composition and an encroaching woody plant in semi-arid rangeland. Basic and Applied Ecology, 13(2): 149-158.

Angassa A, Baars R M T. 2000. Ecological condition of encroached and non-encroached rangelands in Borana, Ethiopia. African Journal of Ecology, 38(4): 321-328.

Angassa A, Oba G. 2007. Relating long-term rainfall variability to cattle population dynamics in communal rangelands and a government ranch in southern Ethiopia. Agricultural Systems, 94(3): 715-725.

Archer S. 1990. Development and stability of grass/woody mosaics in a subtropical savanna parkland, Texas. U.S.A. Journal of Biogeography, 17(4-5): 453-462.

Archer S, Schimel D S, Holland E A. 1995. Mechanisms of shrubland expansion: land use, climate or $\mathrm{CO}_{2}$ ?. Climatic $\mathrm{Change}$ 29(1): 91-99.

Archer S R. 2010. Rangeland conservation and shrub encroachment: new perspectives on an old problem. In: du Toit J T, Kock R, Deutsch J C. Wild Rangelands: Conserving Wildlife While Maintaining Livestock in Semi-arid Ecosystems. Chichester: John Wiley and Sons Ltd., 53-97.

Ayres D, Melville G, Bean J, et al. 2001. Woody Weeds, Biodiversity and Landscape Function in Western New South Wales. Dubbo: WEST 2000, 221.

Bahre C J. 1991. A Legacy of Change: Historic Human Impact on Vegetation in the Arizona Borderlands. Tucson: University of Arizona Press, 231.

Behnke R H, Scoones I, Kerven C. 1993. Range Ecology at Disequilibrium: New Models of Natural Variability and Pastoral Adaptation in African Savannas. London: Overseas Development Institute, 248.

Belay T A, Totland Ø, Moe S R. 2013. Woody vegetation dynamics in the rangelands of lower Omo region, southwestern Ethiopia. Journal of Arid Environments, 89: 94-102.

Bester F, Reed A. 1997. Bush encroachment: a thorny problem. Spotlight on Agriculture, 1: 175-177.

Bews J W. 1917. The plant succession in the Thorn Veld. South African Journal of Science, 14: 163-172.

Biederman L A, Boutton T W. 2009. Biodiversity and trophic structure of soil nematode communities are altered following woody plant invasion of grassland. Soil Biology and Biochemistry, 41(9): 1943-1950.

Bothma J P. 2002. Game Ranch Management (4 $4^{\text {th }}$ ed.). Pretoria, South Africa: Van Schaik Publishers.

Bowman D M J S, Balch J, Artaxo P, et al. 2011. The human dimension of fire regimes on Earth. Journal of Biogeography, 38(12): 2223-2236.

Bradstock R A, Auld T D. 1995. Soil temperatures during experimental bushfires in relation to fire intensity: consequences for legume germination and fire management in south-eastern Australia. Journal of Applied Ecology, 32(1): 76-84.

Briske D D, Fuhlendorf S D, Smeins F E. 2003. Vegetation dynamics on rangelands: a critique of the current paradigms. Journal of Applied Ecology, 40(4): 601-614.

Brown J R, Archer S. 1989. Woody plant invasion of grasslands: establishment of honey mesquite (Prosopis glandulosa var. glandulosa) on sites differing in herbaceous biomass and grazing history. Oecologia, 80(1): 19-26.

Buitenwerf R, Bond W J, Stevens N, et al. 2012. Increased tree densities in South African savannas: >50 years of data suggest $\mathrm{CO}_{2}$ as a driver. Global Change Biology, 18: 675-684.

Clarke P J, Davison E A, Fulloon L. 2000. Germination and dormancy of grassy woodland and forest species: effects of smoke, heat, darkness and cold. Australian Journal of Botany, 48(6): 687-699.

Dregne H E, Choun N T. 1992. Global desertification dimensions and costs. In: Dregne H E. Degradation and Restoration of 
Arid Lands. Lubbock: Texas Technology University, 249-282.

Dregne H E. 2002. Land degradation in the drylands. Arid Land Research and Management, 16(2): 99-132.

Ehleringer J R. 2005. The influence of atmospheric $\mathrm{CO}_{2}$, temperature, and water on the abundance of $\mathrm{C}_{3} / \mathrm{C}_{4}$ taxa. In: Baldwin I T, Caldwell M M, Heldmaier G, et al. A History of Atmospheric $\mathrm{CO}_{2}$ and its Effects on Plants, Animals, and Ecosystems. New York: Springer, 214-231.

Eldridge D J, Wilson B R, Oliver I. 2003. Regrowth and Soil Erosion in the Semi-arid Woodlands of New South Wales. Sydney: NSW Department of Land and Water Conservation, 42.

Eldridge D J, Bowker M A, Maestre F T, et al. 2011. Impacts of shrub encroachment on ecosystem structure and functioning: towards a global synthesis. Ecology Letters, 14(7): 709-722.

Ernst W H O. 1988. Seed and seedling ecology of Brachystegia spiciformis, a predominant tree component in Miombo woodlands in South Central Africa. Forest Ecology and Management, 25(3-4): 195-210.

Fatunbi A O, Dube S. 2008. Land degradation in a game reserve in Eastern Cape of South Africa: soil properties and vegetation cover. Scientific Research and Essay, 3: 111-119.

Friis I, Vollesen K. 2005. Flora of the Sudan-Uganda border area east of the Nile. II. Catalogue of vascular plants, $2^{\text {nd }}$ part, vegetation and phytogeography. Biologiske Skrifter, 51(2): 390-855.

Gemedo-Dalle, Maass B L, Isselstein J. 2006. Rangeland condition and trend in the semi-arid Borana lowlands, southern Oromia, Ethiopia. African Journal of Range and Forage Science, 23(1): 49-58.

Gibbens R P, McNeely R P, Havstad K M, et al. 2005. Vegetation changes in the Jornada Basin from 1858 to 1998 . Journal of Arid Environments, 61(4): 651-668.

Gottfried G J, Allen L S, Warren P L, et al. 2009. Private-public collaboration to reintroduce fire into the changing ecosystems of the southwestern borderlands region. Fire Ecology, 5(1): 85-99.

Grover H D, Musick H B. 1990. Shrubland encroachment in southern New Mexico, U.S.A.: an analysis of desertification processes in the American southwest. Climate Change, 17(2-3): 305-330.

Hottman M T, O’Connor T G. 1999. Vegetation change over 40 years in the Weenen/Muden area, KwaZulu-Natal: evidence from photo-panoramas. African Journal of Range and Forage Science, 16(2-3): 71-88.

Idso S B. 1992. Shrubland expansion in the American Southwest. Climatic Change, 22(1): 85-86.

Illius A W, O’Connor T G. 1999. On the relevance of nonequilibrium concepts to arid and semiarid grazing systems. Ecological Applications, 9(3): 798-813.

Jeltsch F, Milton S J, Dean W R J, et al. 1996. Tree spacing and coexistence in semiarid savannas. Journal of Ecology, 84(4): 583-595.

Kgosikoma O, Mojeremane W, Harvie B A. 2012. Pastoralists' perception and ecological knowledge on savanna ecosystem dynamics in semi-arid Botswana. Ecology and Society, 17(4): 27.

Köchy M, Wilson S D. 2001. Nitrogen deposition and forest expansion in the northern Great Plains. Journal of Ecology, 89(5): 807-817.

Maestre F T, Bowker M A, Puche M D, et al. 2009. Shrub encroachment can reverse desertification in semi-arid Mediterranean grasslands. Ecology Letters, 12(9): 930-941.

Moleele N M, Perkins J S. 1998. Encroaching woody plant species and boreholes: is cattle density the main driving factor in the Olifants Drift communal grazing lands, south-eastern Botswana? Journal of Arid Environments, 40(3): 245-253.

Moleele N M, Ringrose S, Matheson W, et al. 2002. More woody plants? The status of bush encroachment in Botswana's grazing areas. Journal of Environmental Management, 64(1): 3-11.

Morgan J A, Milchunas D G, LeCain D R, et al. 2007. Carbon dioxide enrichment alters plant community structure and accelerates shrub growth in the shortgrass steppe. Proceedings of the National Academy of Sciences of the United States of America, 104(37): 14724-14729.

Moshe D, Bailey C L, Scholes R J. 2000. The effect of elevated atmospheric carbon dioxide on selected savanna plants. In: Seydack A H W, Vermeulen W J, Vermeulen C. Proceedings: Natural Forests and Savanna Woodlands Symposium II: Towards Sustainable Management Based on Scientific Understanding of Natural Forests and Woodlands. Knysna, South Africa: Department of Water Affairs and Forestry, 142-144.

Mphinyane W N, Moleele N M, Sebego R J. 2011. Effect of burning interval on species composition, herbage yield and bush control in the savanna of eastern Botswana. Botswana Journal of Agriculture and Applied Science, 7(1): 96-106.

Noble J C. 1997. The Delicate and Noxious Scrub: CSIRO Studies on Native Tree and Shrub Proliferation in the Semi-arid Woodlands of Eastern Australia. Canberra: CSIRO.

Nott K, Savage M J. 1985. Observations on the utilization of a dune succulent by Namib faunae. South African Journal of Zoology, 20(4): 269-271. 
Oba G, Post E, Syvertsen P O, et al. 2000. Bush cover and range condition assessments in relation to landscape and grazing in southern Ethiopia. Landscape Ecology, 15(6): 535-546.

O’Connor T G. 1991. Local extinction in perennial grasslands: a life-history approach. The American Naturalist, 137(6): 753-773.

O’Connor T G, Puttick J R, Hoffman M T. 2014. Bush encroachment in southern Africa: changes and causes. African Journal of Range \& Forage Science, 31(2): 67-88.

Polley H W, Johnson H B, Mayeux H S. 1992. Carbon dioxide and water fluxes of $\mathrm{C}_{3}$ annuals and $\mathrm{C}_{3}$ and $\mathrm{C}_{4}$ perennials at subambient $\mathrm{CO}_{2}$ concentrations. Functional Ecology, 6(6): 693-703.

Price J N, Morgan J W. 2008. Woody plant encroachment reduces species richness of herb-rich woodlands in southern Australia. Austral Ecology, 33(3): 278-289.

Prins H H T, Van der Jeugd H P. 1992. Growth rates of shrubs on different soils in Tanzania. African Journal of Ecology, 30(4): 309-315.

Ratajczak Z, Nippert J B, Collins S L. 2012. Woody encroachment decreases diversity across North American grasslands and savannas. Ecology, 93(4): 697-703.

Reich P, Eswaran H, Kapur S, et al. 2000. Land degradation and desertification in desert margins, International Symposiumon Desertification/2000-Konya. [2004-10-29]. http://www.toprak.org.tr/isd/isd.

Reynolds J F, Smith D M S, Lambin E F, et al. 2007. Global desertification: building a science for dryland development. Science, 316(5826): 847-851.

Richardson F D, Hahn B D, Hoffman M T. 2005. On the dynamics of grazing systems in the semi-arid succulent Karoo: The relevance of equilibrium and non-equilibrium concepts to the sustainability of semi-arid pastoral systems. Ecological Modelling, 187(4): 491-512.

Richter C G F, Snyman H A, Smit G N. 2001. The influence of tree density on the grass layer of three semi-arid savanna types of Southern Africa. African Journal of Range and Forage Science, 18(2-3): 103-109.

Roques K G, O’Connor T G, Watkinson A R. 2001. Dynamics of shrub encroachment in an African savanna: relative influences of fire, herbivory, rainfall and density dependence. Journal of Applied Ecology, 38(2): 268-280.

Russell J, Ward D. 2014. Vegetation change in northern KwaZulu-Natal since the Anglo-Zulu War of 1879: local or global drivers?. African Journal of Range and Forage Science, 31(2): 89-105.

Sankaran M, Ratnam J, Hanan N P. 2004. Tree-grass coexistence in savannas revisited-insights from an examination of assumptions and mechanisms invoked in existing models. Ecology Letters, 7(6): 480-490.

Sankaran M, Hanan N P, Scholes R J, et al. 2005. Determinants of woody cover in African savannas. Nature, 438(7069): 846-849.

Sankaran M, Ratnam J, Hanan N. 2008. Woody cover in African savannas: the role of resources, fire and herbivory. Global Ecology and Biogeography, 17(2): 236-245.

Schmutz E M, Smith E L, Ogden P R. 1991. Desert grassland. In: Coupland R T. Natural Grasslands: Introduction and Western Hemisphere. Amsterdam: Elsevier, 337-362.

Scholes R J, Archer S R. 1997. Tree-grass interactions in savannas. Annual Review of Ecology and Systematics, 28: 517-544.

Skarpe C. 1990. Structure of the woody vegetation in disturbed and undisturbed arid savanna, Botswana. Vegetation, 87(1): $11-18$.

Smit G N. 2003. The Importance of Ecosystem Dynamics in Managing the Bush Encroachment Problem in Southern Africa. Bloemfontein: University of the Free State. In: Proceedings of the Seventh International Rangelands Congress, 26 July-1 August 2003, Durban, South Africa, 14-22.

Smith D L, Johnson L. 2004. Vegetation-mediated changes in microclimate reduce soil respiration as woodlands expand into grasslands. Ecology, 85(12): 3348-3361.

Tefera S, Snyman H A, Smit G N. 2007. Rangeland dynamics in southern Ethiopia: (3). Assessment of rangeland condition in relation to land-use and distance from water in semi-arid Borana rangelands. Journal of Environmental Management, 85(2): 453-460.

Tessema Z K, de Boer W F, Baars R M T, et al. 2012. Influence of grazing on soil seed banks determines the restoration potential of aboveground vegetation in a semi-arid savanna of Ethiopia. Biotropica, 44(2): 211-219.

UNCCD, UNDP, UNEP. 2009. Climate Change in the African Drylands: Options and Opportunities for Adaptation and Mitigation. Bonn, New York and Nairobi: UNCCD, UNDP and UNEP.

Van Auken O W, Gese E M, Connors K. 1985. Fertilization response of early and late successional species: Acacia smallii and Celtis laevigata. Botanical Gazette, 146(4): 564-569.

Van Auken O W. 2000. Shrub invasions of North American grasslands. Annual Review of Ecology and Systematics, 31: 
192-215.

Van Auken O W. 2009. Causes and consequences of woody plant encroachment into western North American grasslands. Journal of Environmental Management, 90(10): 2931-2942.

Vetter S. 2005. Rangelands at equilibrium and non-equilibrium: recent developments in the debate. Journal of Arid Environments, 62(2): 321-341.

Ward D. 2005. Do we understand the causes of bush encroachment in African savannas? African Journal of Range and Forage Science, 22: 101-105.

Ward D, Hoffman M T, Collocott S J. 2014. A century of woody plant encroachment in the dry Kimberley savanna of South Africa. African Journal of Range and Forage Science, 31(2): 107-121.

Walter H. 1939. Grassland, savanna and bush in arid parts of Africa and their ecological dependence. Jahrbücher für Wissenschaftlike Botanik, 87: 750-860. (in German)

Walker H. 1971. Ecology of Tropical and Subtropical Vegetation. Edinburgh, UK: Oliver and Boyd.

Westoby M, Walker B, Noy-Meir I. 1989. Opportunistic management for rangelands not at equilibrium. Journal of Range Management, 42(4): 266-274.

White F. 1983. The vegetation of Africa. A descriptive memoir to accompany the Unesso/AETFAT/UNSO vegetation map of Africa (3 plates), 1:5,000,000. Paris: UNESCO.

Zewdu T, Oustelet Y. 2007. Vegetation composition, biomass production, carrying capacity and grassland types in Odolla Area of Shinile Zone, Eastern Ethiopia. East African Journal of Sciences, 1(2): 148-159. 